\title{
Ephemeral graphic language: from the blackboard to the students' repertoire
}

Renata Cadena renatx@gmail.com UFPE, Brasil

Cadena, Renata; (2012) "Ephemeral graphic language: from the blackboard to the students' repertoire", p. 246-250 . In: Barbosa, Helena; Quental, Joana [Eds]. Proceedings of the 2nd International Conference of Art, Illustration and Visual Culture in Infant and Primary Education. São Paulo: Blucher, 2015. ISSN 2318-695X, ISBN: 978-989-98185-0-7 DOI 10.5151/edupro-aivcipe-47

Abstract

On this article, there is a description of a study concerning the graphic messages created by Brazilian teachers on the blackboard, within the basic education system - denominated by Cadena (2010) as Ephemeral Graphic Language (EpGL). A field research has been conducted in five schools from Recife, and it is discussed, so as the analysis patterns and its results of three main aspects: a) analysis of formal issues of the message; b) categorization of the messages in five kinds of use; and c) comparison of the transcription made by the students of the original message on the blackboard. The conclusion indicates a lack of reflection and attention to the graphic language as an important tool for the construction of knowledge.

Keywords blackboard, graphic language, information design, education

The field study had ethnographic bases and the method used was the non-participant observation. The researchers took part in the ordinary actions of five schools without interfering in its context. The activities were registered with a research diary, photos and videos of the moments when the blackboard was being used, in addition to photographs of the students' transcriptions.

The grade selected was the primary school's third year (on which children are about 7 to 8 years), because the students can already read and they have at least one year of practice. Besides, this age group aligns with other researches of the research project Ensina Design.

Then, five schools from Recife were visited, three of which were public institutions and two private. The first two visited schools have had two classes accompanied in each, totaling seven classes observed. As there was just one 'main' teacher for each classroom, the seven teachers, all female, had their work observed on these disciplines: Portuguese language, mathematics, science, history and geography. In public schools, the teachers were also responsible for the discipline of art, while in private schools, there was a specific teacher and a lab for it. Each group was accompanied by a week, approximately, totaling about 85 hours of observation.

The raised data had to be translated in units that allow the analysis, so then 'ephemeral graphic messages' were defined as the information compositions that had an unified communication purpose. This had to be defined because several simultaneous graphic messages share the same chalkboard, as it was observed on a class that the blackboard had concurrently a list of activities to be held, the names of some students who would not have recess, and the responses for an exercise. 
2nd International Conference Art, Illustration and Visual Culture in Infant and Primary Education $2^{\circ}$ Congreso Internacional

Arte, Ilustración y Cultura Visual en Educación Infantil y Primaria
Congresso Internacional

de Arte, Ilustracão e Cultura Visual

na Educação Infantil e Primária

\section{Analysis and results 2.1 Graphic analysis of the collected EpGL}

Figure 1. Spontaneous explanation on a private school. Figure 2. List of activities for the day on a public school. Figure 3 . Class work and explanation on a public school. Source of the three images: the researchers.
The review of the graphic language of the collected messages adopted the ideas proposed by Twyman $(1979,2002)$ on his 'schema for the study of Graphic Language'. Presented in matrix format, this diagram relates the 'methods of configuration' on the columns to the 'modes of symbolization' on the lines, so the resulting cells of this table comprise the most common forms of communication through graphic language.

Modes of symbolization suggest how the graphic language can be symbolized - by means of words and digits (verbal-numeric), drawings and photographs (pictorial), graphics and all that is not decidedly verbal or pictorial (schematic). And methods of configuration indicates how information can be organized spatially, such as 'pure linear' (like the drawings on Trajan's column); 'linear interrupted' (like this article); 'list'; 'linear branching' (as a flowchart); 'matrix'; 'non-linear directed viewing' (when the message does not suggest a direction of reading, but there are attention spots); and 'non-linear most options open' (like on those "Where's Waldo" magazines)

Twyman (1979:118) introduced the scheme as "an instrument to direct the thought", allowing new uses of the graphic language, because he believes that its greatest goal is to demonstrate the wide variety of graphic language's uses.
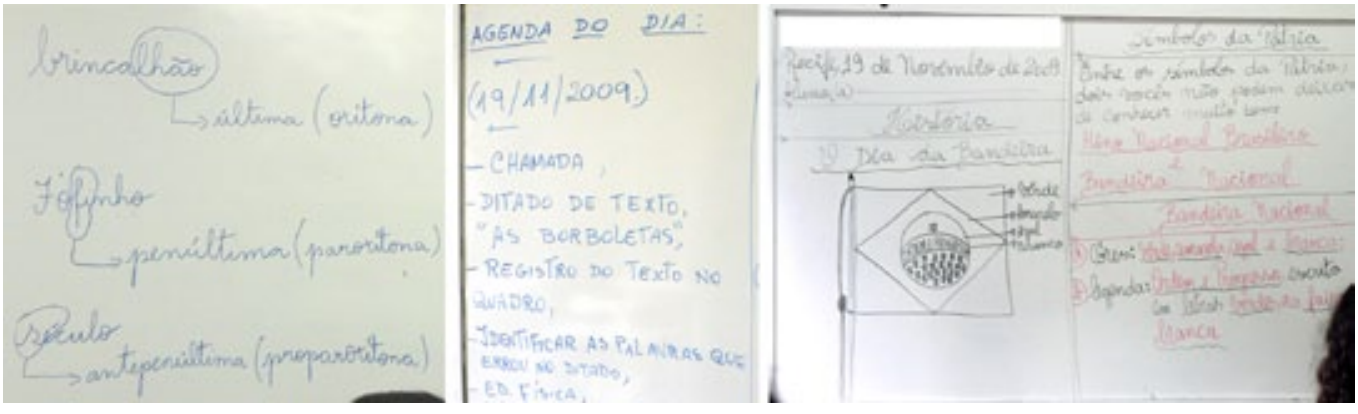

The ephemeral collected graphic messages were analyzed concerning Twyman's model. It has been noticed that the most common mode of symbolization was the verbal-numeric. The teachers' handwriting, in general, was cursive and large, although some teachers also used the so-called 'block letters' (uppercase, with no links between the characters); and they usually explained the children when there was any different handwriting.

Almost all teachers used the pictorial mode, however they were often stereotypical images (figure 3). In private schools, this is not totally a problem, since these drawings were referring to a content that have already been worked in the textbook or on posters. In public schools, in turn, often a drawing was the only representative imagery to develop some concepts. All teachers used the schematic mode as a complement to verbal language, especially to highlight words or phrases on the blackboard. Its use was also common to organize the blackboard or to help the transcription, as the example of the notation ' $x$ ' indicating that the student should skip a line in the notebook. Only in few situations the schematic graphic language had been directly associated with the formal content.

Concerning the methods of configuration, there was a relatively diverse production, with some few examples of linear branching (figure 1), lists (figure 2), and matrices. These cases, however, represent exceptions before the massive use of more conventional methods, which are associated with the work of non-experts. The teachers use the configuration methods that are more familiar to them, because they had not studied graphic language on its diversity and features. An influence of the graphic language of the textbooks on the teachers' graphic language was noticed, as the correlation between the method of configuration and the activity type used by the teachers was very similar to the one shown in the textbooks adopted. But this was just slightly observed and deserves further analysis. 
$2^{\text {nd }}$ International Conference Art, Illustration and Visual Culture in Infant and Primary Education $2^{\circ}$ Congreso Internacional

Arte, Ilustración y Cultura Visual en Educación Infantil y Primaria
Aresso Internacional

de Arte, Illustracãa e Cultura Visual

na Educação Infantil e Primária
Overall, the teachers usually begin the copies on the left side of the chalkboard and organize the content into columns, making the use of lines to limit them. However, when they feel the need to demonstrate something spontaneously, they produce the messages on the nearest available space.

\subsection{Categorization of the functions of the collected EPGL}

Figure 4. The graph shows the distribution of the category of EpGL uses. Source: researchers. Figure 5. The graph compares the different private and public schools' uses of EpGL. Source: researchers.
It was possible to see patterns on the purposes that made the teachers use EpGL by taking into account: a) the type of response that was expected of the student (to copy, to observe, to participate), b) the intention of the teacher, and c) the content of messages. Thus, five categories were indentified.

The term guide to copy defines the messages that generally contain formal content and other information, and its main function is to guide the transcription that the students make on their agendas, notepads, sketchbooks, etc (figure 3). Guide for comparison refers to the message with information that should be compared with another content. It is generally used in the collective correction of exercises, in which the teacher writes on the desired response, the students compare with their own answers and, if it is wrong, they copy the response of the board. Sometimes, students are asked to write their own answers on the board, which is a way to capture the interest and involve them in the classroom, as one of the teachers said.

The category explanation includes messages that are meant to graphically represent a concept or abstract content, demonstrating or deepening any idea (figure 1). In general, these experiences are spontaneous and its development is accompanied with curiosity by the students, who generally do not copy what is being written / shown. Collective activity refers to messages that use the active participation of students in the content or in its construction. They write on the blackboard themselves, and the construction of these compositions is a didactical activity itself. And the last category is called regulation, on which the blackboard has the function to help the teachers to organize the dynamics of the class (figure 2). They are normative messages, which the teacher writes for consultation by the students, and should not be copied by them.
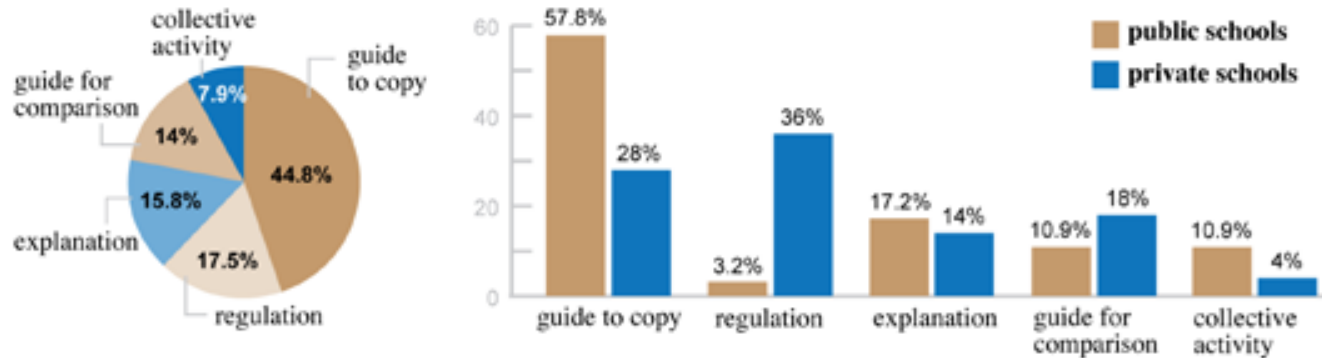

Using these categories to analyze the EpGL, the most recurred function was the guide to copy, which was used to texts and exercises, accounting almost half of all uses (Figure 4). There has been a difference on the types of messages used on private and public school, which was an important issue to be shown (Figure 5). One of the main reasons are due to the different material reality of the two types of institution; and mainly because the use of textbooks was very limited in the public ones, for reasons such as inadequacy of its content. In this case, the content and exercises are written on the blackboard by the teacher, so the student can transcribe to the notebook, while in private schools, this function was mainly used for copying reminders on the agenda. Thus, on these schools, the most used function was regulation, while on public schools it is the least common category, and even the collective activities are more used there.

For each monitored class, a sample of EpGL has been chosen - and in order to allow a comparison of children transcription, the same amount of copies on agendas, notepads or paper sheets was randomly chosen. It means that for each message on the blackboard, four transcription had been chosen and analyzed, regarding the content of the message, its 
2nd International Conference Art, Illustration and Visual Culture in Infant and Primary Education $2^{\circ}$ Congreso Internaciona

Arte, Ilustración y Cultura Visual en Educación Infantil y Primaria
'Congresso Internacional

de Arte, Ilustração e Cultura Visual

na Educação Infantil e Primária
Figure 6. Part of a message on the blackboard. Figures 7, 8 and 9 . Transcription of the corresponding message on figure 7 . Source: the researchers. information design, and if the commands indicated on the blackboard had been represented (e.g. when the teacher puts some small ' $x$ ' meaning that the children has to 'skip' a line on their notepads).

The content has been usually copied on its totality, but some words have been replaced by synonyms or written with different spelling (like handwritten typos) - which indicates that the children has once read the text and has copied it after, instead of copying letter by letter.
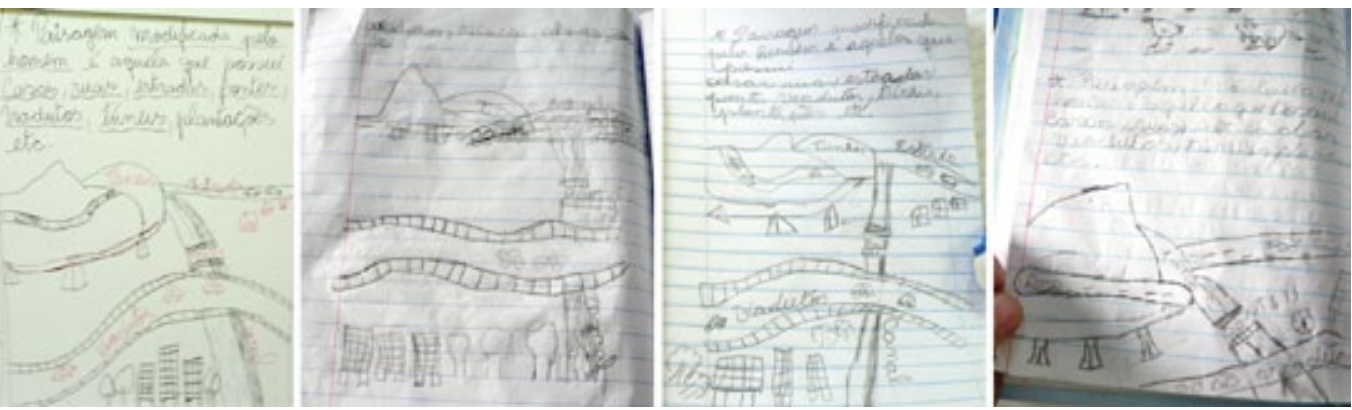

The information design has been analyzed in some aspects, as the verbal graphic language, the pictorial graphic language and the schematic graphic language. The first one was the most used representation mode, and was analyzed on its extrinsic and intrinsic features. The handwriting used by the children was on its majority very similar to the one used by the teacher $\urcorner-$ in terms of cursive writing or printed letters. Concerning the use of capital or small letters, most students have also followed the teacher's writing on the blackboard. The sentences distribution on the transcription, or the paragraph and line breaks, were also strictly followed by the students and in some cases, so strictly that the children still have place to continue the sentence on the text line, but they went to the other line just like it was displayed on the blackboard (figure 8, the third line). This kind of error happened only in two classes, and the ones that have the blackboard messages mostly as a copy guide, what indicates the use of the copy merely as a mechanical activity, without deep reflection about writing rules or organization. And about the text alignment and the indentation, at large, the students' transcription also had remained reliable to the teacher sentences organization.

For the pictorial graphic language, the transcription was similar to the texts: they copied the drawings with care, reproducing the elements, their position and proportions (figures 6 to 9). Concerning the schematic graphic language, most teachers used it, but the kids have been neglected its transcription more often than the other symbolization modes. That could be an evidence of the student's unawareness of the meaning and importance of these marks to the message.

This exploratory research has shown issues not only on the use of the EpGL, its formal attributes or its relationship with the student, but also indicates how graphic education is in Brazil. All the participant teachers said they hadn't received specific classes about how to deal with the graphic language on their routine, so as on the main schools and university for teachers on Recife, there is not any specific training on the curriculum (Cadena, 2010). Lopes \& Coutinho (2011) also reinforce that this is a missing subject even on the graduation in art education.

The analysis of the methods of configuration and the modes of symbolization has shown that there is not much variation on what the teachers usually create. The widely used form of message was the verbal-numeric mode displayed in interrupted lines - the most common information representation to non-experts in graphic language. So, it brings out the question: should teaching be treated as some others professions (that do not make too much use of the graphic language and do not need to use it properly), if teachers have to deal with it on their daily routine at school?

The form of the analyzed message was related to its function - the linear interrupted was common to the 'guides' categories; the list was linked to regulation messages and non-linear organizations were common to collective activities. But the great use of the messages as guides 
$2^{\text {nd }}$ International Conference Art, Illustration and Visual Culture in Infant and Primary Education

to copy speaks by itself: that the children relationship with their teacher graphic language is mostly about copying, instead of discussing, reflecting, creating. The different panorama on private schools shows up that there are other - and maybe better - instruments to keep and exercise the content instead of copying, like textbooks. So the found unsuitability between instrument and action is also a design issue, as should other didactical graphic artifacts should be, as defends Coutinho (2008), explaining that designers are experts on communication and information.

The transcription analysis shows that those children usually copy exactly what the teacher has written/drawn, because it was their teacher's command. The act of copy, itself, has its didactical importance and also contributes to the development of the graphical security on children, but it was verified that sometimes, the students have seemed not to understand properly what they were copying. Also, these literal transcriptions could be related to their incipient relationship with the graphic world, but it needs further research to confirm that.

\section{References}

Cadena, R. A. (2010). Linguagem gráfica efêmera: uma investigação acerca das mensagens produzidas no quadro em escolas do Recife de ensino fundamental. Mastermind: Solange G. Coutinho. Nonpublished monograph. Recife: Universidade Federal de Pernambuco.

Coutinho, S. G. 2008. Ensina Design: A introdução de conteúdos de Design Gráfico no currículo do Ensino Fundamental Brasileiro. Research project approved by CNPq, but non-published. Recife: Universidade Federal de Pernambuco.

Coutinho, S. G \& Lopes, M. T. (2011). Design para educação: uma possível contribuição para o ensino fundamental brasileiro. In: Braga, M. C. (Org.), O Papel social do design gráfico: história, conceitos \& atuação profissional. São Paulo: Editora SENAC, p.137-162.

Twyman, M. L. (1979). A schema for the study of graphic language. In: Paul A. Kolers, Merald E. Wrolstad \& Herman Bouma (Eds.). Processing of visible language. Nova York \& Londres: Plenum Press, vol.1, pp.117-150.

Twyman, M. L. (2002). Further thoughts on a schema for describing graphic language. In: Proceedings of the 1st International Conference on Typography and Visual Communication, Thessaloniki, Greece: University of Macedonia Press, pp. 329-350. 